WellBeing International

WBI Studies Repository

2007

\title{
Enforcing Wildlife Protection in China
}

Peter J. Li

University of Houston

Follow this and additional works at: https://www.wellbeingintlstudiesrepository.org/acwp_awap

Part of the Animal Law Commons, Animal Studies Commons, and the Other Anthropology Commons

\section{Recommended Citation}

$\mathrm{Li}, \mathrm{P}$. J. (2007). Enforcing wildlife protection in China the legislative and political solutions. China Information, 21(1), 71-107.

This material is brought to you for free and open access by WellBeing International. It has been accepted for inclusion by an authorized administrator of the WBI Studies Repository. For more information, please contact wbisr-info@wellbeingintl.org.

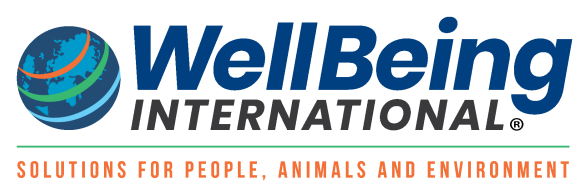




\section{Enforcing Wildlife Protection in China}

The Legislative and Political Solutions

Peter J. Li

University of Houston

\section{KEYWORDS}

law, economic growth, wildlife protection, wildlife crisis

\section{ABSTRACT}

Since China enacted the Wildlife Protection Law in 1988, its wildlife has been threatened with the most serious survival crisis. In the prereform era, wildlife was a neglected policy area. Serving the objective of reform, the Wildlife Protection Law upholds the "protection, domestication, and utilization" norm inherited from past policies. It establishes rules for wildlife management and protection. This law provides for penalties against violations. Yet, its ambiguous objectives, limited protection scope, and decentralized responsibilities have made its enforcement difficult. Political factors such as institutional constraints, national obsession with economic growth, shortage of funding, and local protectionism have made the Wildlife Protection Law enforcement an uphill struggle. This study calls for a revision in the Wildlife Protection Law to drop the "protection for human use" objective, expand protection scope, introduce anticruelty provisions, and nationalize protection responsibilities. Understanding that the current one-party state will continue in the foreseeable future, this article calls for moves to open up China's policymaking to advocacy groups. China's wildlife crisis requires both short-term legislative and long-term political solutions.

The outbreak of SARS (severe acute respiratory syndrome) in 2003 attracted worldwide attention to China's wildlife crisis. The epidemic, which erupted in China's Guangdong Province, was reportedly linked to highly identical viruses in the various wildlife species traded and eaten in the province. ${ }^{1}$ Government measures to stop the spread of the disease in the wake of its outbreak led to the discovery of widespread violations of state laws and regulations protecting the nation's wildlife. ${ }^{2}$ In Guangdong's live animal markets, visitors could buy anything that was creepy, feathery, crawly, and slippery. Significant numbers of wildlife animals freshly caught in the wild often had gaping wounds and dangling limbs. Many of them were state-protected species. ${ }^{3}$

China's wildlife crisis is nationwide in scale. Wildlife eating, an erstwhile regional culinary subculture in South China, has spread to the rest of the Chinese mainland. Shanghai reportedly consumed as many live snakes a year as Guangzhou, China's capital of wildlife eating. ${ }^{4}$ Commercial exploitation of wildlife is a booming business. Wildlife farming, a formerly state-monopolized production, has become a lucrative business mostly in private hands. Today, China boasts the world's biggest wildlife domestication operation. ${ }^{5}$ Its bear farming is arguably the world's biggest with some 7,000 Asiatic black bears 
incarcerated for the extraction of bile, the so-called "liquid gold." According to an investigation published in early 2005, China also has the world's biggest fur animal farming operation. Investigators uncovered the shocking conditions in which these fur animals are raised, transported, and slaughtered. ${ }^{6}$

Does China have legal protection for its wildlife? If such laws exist, what has gone wrong? This article joins the discussion on China's wildlife protection. It asks whether the Wildlife Protection Law is flawed as the Chinese critics have claimed. What other factors could have hindered the enforcement of China's Wildlife Protection Law and wildlife protection in general? What should be done to improve the enforcement of the Wildlife Protection Law?

\section{Wildlife protection: legacy and new challenges}

China is endowed with abundant wildlife species. With only $6.5 \%$ of the world's territory, it is home to more than 6,347 species of vertebrates, some $14 \%$ of the world's total. ${ }^{7}$ Of these vertebrates, China has 711 species of mammals, 3,862 species of fish ( $20 \%$ of the world's total), 1,244 species of birds ( $13.7 \%$ of the world's total), 320 species of reptiles, and 210 species of amphibians. Wildlife animals unique to China include the giant panda, South China tiger, golden-haired monkey, Chinese river dolphin, and Chinese alligator to name the most famous. Many wild species found in other countries also call China home. These include Asiatic elephants, Siberian tigers, Asiatic brown and black bears, Mongolian gazelles, and pangolins. Each year, China becomes a temporary sanctuary for hundreds of thousands of migratory birds. Like all other countries, China has in the last half century faced increasing wildlife devastation.

\section{The legacy of the prereform era}

Wildlife-related policymaking started in 1950 when the Chinese communists took power on the Chinese mainland. The 1950 Measures on Protecting Rare Wildlife Animals were aimed at regulating hunting activities that were taking advantage of regime change on the Chinese mainland. These measures also established the new state's authority in wildlife management. Since then, the new government passed other administrative rules on hunting, aquatic resource management and farming, and forest protection. In response to legislative proposals from deputies at the first National People's Congress, the State Council approved in 1956 the creation of China's first nature reserve. In 1965, 18 more nature reserves were established. In the prereform era, economic recovery, institution building, socioeconomic transformation, and ideological campaigns attracted much more government attention. ${ }^{8}$

Yet, the limited number of administrative regulations put forward important guidelines for managing the nation's wildlife. First, the 1950 Measures on Protecting Rare Wildlife Animals established the state as the guardian of the nation's wildlife. The 1962 State Council Instructions on Actively Protecting and Reasonably Using Animal Resources reaffirmed the state's exclusive authority in wildlife management. Second, the 1957 rules on hunting, the 1961 Forestry Ministry notice on strengthening wildlife management, and the 1962 State Council Instructions listed species for state protection because of their endangered status. Third, the same rules, notices, and instructions banned indiscriminate hunting and mass-killing hunting gear. Finally, the regulations advanced the principles of "protection, domestication, and hunting" for guiding wildlife management. To the government, wildlife was part of the country's natural resources. Protection and domestication were means to the end of human utilization.

Several observations can be made of the prereform wildlife policy and the policy environment. First, it was less a policy of wildlife protection than one of resource management. The 1962 State Council Instructions, for example, shed light on the various economic benefits of the nation's wildlife. ${ }^{9}$ Protection was for 
reasonable use of the wildlife resources. It was only during 1961-2 when China's wildlife was devastated because of an out-of-control hunting spree that protection was temporarily emphasized over utilization.

Second, the prereform policy lacked clarity where rewards and penalties were concerned. The 1962 State Council Instructions contained detailed policies regarding wildlife management and protection. Yet, they made no reference to rewards and penalties for policy compliance and violations. Ironically, the state's own behavior contradicted its policy on wildlife protection. Until the mid-1970s, the Chinese government had continued to procure tiger pelts despite the tiger's status as a state-protected species. In 1956, 1966, and 1974 , for example, the state procured 977,209 , and 14 tiger skins respectively. ${ }^{10}$

Third, the political atmosphere in the prereform era was not conducive to wildlife protection. Viewing wildlife animals as anything other than resources was problematic. In the prereform era, China extolled the human conquest of nature. Mao's war against nature, particularly his call to exterminate sparrows in 1958, helped reinforce societal prejudice against nonhuman species. ${ }^{11}$ Until very recently, many wildlife animals were still considered "pests" or "injurious beasts." ${ }^{12}$ Finally, food shortage reigned the most part of the prereform era. The great famine of 1960-2 caused by Mao's Great Leap Forward led to a runaway assault on the nation's wildlife. To tide over the man-made "tyranny of scarcity," government offices, soldiers, and ordinary citizens went on a hunting spree of indiscriminate killing. According to official statistics, Sichuan alone wiped out 62,000 deer in the wild in $1960 .{ }^{13}$ The Mongolian gazelle was hunted to near extinction. ${ }^{14}$

Despite the scant attention on wildlife protection in the prereform era, there was no prolonged assault on wildlife on a nationwide scale. Under the people's commune system, Chinese peasants were locked to the collective land. Individual profit-seeking activities were banned. Wildlife farming was a statemonopolized operation. So was wildlife trade.

\section{The new era and new challenges}

The post-Mao Chinese leadership initiated the reform and open policy in 1978, after which China's wildlife management entered a new era. By the mid-1980s, unauthorized hunting had increased. Wildlife animals were hunted and sold to wildlife farms, pharmaceutical companies that had long been frustrated with a shortage of animal parts, and state trade firms dealing in wildlife exports. A significant number of the animals hunted were state-protected endangered wildlife species. To curb the sudden increase in unauthorized hunting, the State Council issued in April 1983 the first administrative order since 1962 on wildlife protection. ${ }^{15}$

A second new development was the mushrooming of wildlife farming operations. The reform policy was aimed at liberating productivity. Decollectivization and policy support of diversified production saw peasant entry into varieties of agricultural or nonagricultural sideline productions. In the mid-1980s, the formerly state-monopolized wildlife farming began to be overshadowed by private businesses. Many of today's big wildlife farms were started at this time. For example, China's biggest bear farm that boasts a stock of more than 1,000 bears opened in 1983 as a small family operation managing only three wild bears. Seed animals purchased by most wildlife farming operations were illegally hunted in the wild. In addition to the increase in unauthorized hunting to supply the new business ventures of small householdbased wildlife farming, existing state regulations did not contain provisions on licensing and administration fee requirements for private wildlife farms. By the end of 1987, the Chinese government had concentrated on cracking down on the widespread illegal hunting and trafficking of protected species. For this purpose, it issued four administrative orders $(1983,1985,1986$, and 1987). Regulation of wildlife farming was delayed. 
Wildlife had long been part of China's trade with the outside world. In 1978, it exported US\$150 million worth of wildlife products, approximately the value of exported frozen mutton, beef, sheep hides, and products of 10 other farm animals. ${ }^{16}$ China was also a major destination for foreign wildlife products such as elephant trunks, tiger bones and parts, and rhino horns. Increased access to the Chinese mainland has also made China's inland provinces targets of transnational smuggling of Chinese wildlife and products. Between 1978 and 1986, Chinese musk smuggled to Japan reached 46,420 ounces. On average, 5,140 ounces went to Japan every year. In 1986 alone, some 7,560 ounces were smuggled to Japan. In the first five months, musk illegally sold to Japan went up to 14,100 ounces. Every ounce of musk comes from 10 musk deer shot in the wild. At the same time, mainland wildlife and products were smuggled to Hong Kong in unprecedented quantities. In 1984 alone, Hong Kong customs uncovered 43 cases of illegal wildlife smuggling involving 5,700 wildlife animals. In 1987, Hong Kong customs even found three panda pelts. The impact of the illegal trade on China's wildlife species was apparent. By the mid-1980s, more than 20 species in China were near extinction. ${ }^{17}$

The new challenges in the reform era called for new policies in the area of wildlife management and protection. In December 1980, China joined the Convention on International Trade of Endangered Species (CITES) and issued four administrative orders. It also signed a bilateral agreement with Japan on the protection of migratory birds. In 1983, the Chinese government appealed to the international community for assistance when the panda's staple food, that is arrow bamboo, was withering in a nature reserve. The new policy documents and actions, though limited in number, showed some changes in the Chinese government's attitude towards wildlife. In a 1983 State Council order, the Chinese government, for the first time, acknowledged the ecological importance of wildlife. Its accession to the Convention on International Trade of Endangered Species and open appeal for help on panda protection signified China's willingness to engage foreign partners in China's wildlife protection. The challenges and the new attitude motivated China to elevate wildlife protection to a new height.

\section{Legislating wildlife protection}

The Wildlife Protection Law of 1988 signaled the elevation of the level of state protection for China's wildlife. The law contains five chapters and 42 articles. These articles cover provisions on wildlife ownership, scope of protection, protection and management mechanisms, and penalties for law violation. The law addresses issues such as wildlife farming that had been neglected in past policies. Since 1988, the Wildlife Protection Law has been revised once to include an article on the management of hunting grounds for foreigners.

\section{Objectives and scope of protection}

The Wildlife Protection Law advances two objectives. It promotes wildlife protection, rescue, domestication, and reasonable utilization (Art. 1, Ch. I). This objective reflects the guiding principles of "protection-domestication-hunting" of the 1962 State Council policy, and it derives from the official position that wildlife species are part of the natural resources to be used for human benefit. Protection is necessary because "wildlife resources can be used in a sustainable way if they are properly managed and protected." ${ }^{18}$ The Wildlife Protection Law also aims to promote ecological balance through wildlife management and protection.

In view of the new situation of wildlife crisis, the Wildlife Protection Law groups China's rare and endangered species - the target of illegal hunting and trafficking-into two classes for state protection. In January 1989, the forestry and agriculture ministries jointly published the lists of state-protected Category I and Category II wildlife species. ${ }^{19}$ Included in Category I are the rare and endangered species such as giant pandas, Chinese river dolphins, Asiatic elephants, golden-haired monkeys, monitors, ibis, 
redcrested cranes, and 109 other species. Category II species include brown and black bears, pangolins, salamanders, Mongolian gazelles, Tibetan monkeys, snow leopards, Taiwanese monkeys, and 301 other species. Most of these rare and endangered species had been coveted by poachers and smugglers by the time the Wildlife Protection Law was enacted. In 1993, in line with the Chinese government's commitment to the international ban on trade in endangered species, to alleviate international pressure, and to assist China's Olympic Games bid, the Chinese government announced that the rhinoceros, ostrich, African elephant, zebra, and other non-Chinese species were under China's protection. ${ }^{20}$ Additionally, the Chinese government in 2000 expanded the state's protection list to include species of economic and scientific value, among which were 88 species of mammals, 707 species of birds, 291 species of amphibians, 395 species of reptiles, and 110 species of insects. ${ }^{21}$

Ownership, administration, and guiding principle

The Wildlife Protection Law states that wildlife ownership falls under the state's responsibility (Art. 3). The state manages the nation's wildlife through the state and provincial forestry, fishery, and other ministerial agencies (Art. 7). These agencies are authorized to approve the hunting of the protected species for research, domestication, exhibition, or other special purposes (Art. 16). Specifically, the national wildlife administrations handle requests for state-protected Category I species while their provincial counterparts approve requests for state-protected Category II species (Art. 16).

China has a long history of wildlife use. The Wildlife Protection Law therefore reiterates the state's support for wildlife domestication (Art. 17): "The state upholds the principle of strengthening the protection of wildlife resources, actively domesticating and breeding wildlife species, rationally developing and utilizing wildlife resources, and encouraging scientific research on wildlife." To manage the nation's thriving wildlife businesses, the Wildlife Protection Law advances mechanisms for business registration and for fee collection.

\section{Protection and management}

The Wildlife Protection Law stipulates six important protection tasks to be fulfilled by the provincial wildlife administrations. The tasks are as follows:

1. ban unauthorized hunting and killing of state- and locally-protected species (Art. 8, Ch. II);

2. maintain and update a list of the protected species (Art. 9, Ch. II);

3. establish and manage nature reserves (Art. 10, Ch. II);

4. monitor and investigate environmental impact on wildlife (Art. 11, Ch. II);

5. rescue protected species threatened by natural disasters (Art. 13, Ch. II); and

6. compensate damages incurred in wildlife protection (Art. 14, Ch. II).

The Wildlife Protection Law also contains stipulations on wildlife management. A regular survey of the nation's wildlife resources is to be conducted every 10 years (Art. 15, Ch. III). Wildlife administrations at the provincial level are authorized to handle and manage permit issuance (Art. 17). Authorized hunting, according to the Wildlife Protection Law, must comply with the requirements on hunting quantity, hunting rifles, species for hunting, hunting location, and duration. No military weapons, poisons, and explosives are allowed in hunting. The production and sales of hunting rifles and ammunitions are to be regulated by the forestry administration in collaboration with the State Public Security Department (Arts. 18, 19, 20, 21). Local governments above the county level shall identify the prohibited hunting gear and methods (Art. 20). The Wildlife Protection Law also lists stipulations on interprovincial and transnational transport of the protected species. Documents such as transport permits, import and export permits, and 
quarantine records must be produced. Customs can stop the shipment if the required documents are not in place (Arts. 23 and 24, Ch. III).

An important part of wildlife management is the administration of fee collection. Businesses dealing in wildlife species must pay administration fees to the state wildlife resource. The fee collection standards are to be determined by the forestry administration together with the state finance and price departments (Art. 27). In 1992, the Forestry Ministry, Finance Ministry, and State Price Administration jointly issued Measures for the Collection of Administration Fees for Protecting Terrestrial Wildlife Resources. In 2000, the State Planning Commission and Finance Ministry issued a Notice on the Standards of Fees Collected for Managing the Import and Export of Wildlife Plants and Animals. According to the 1992 "Measures," fixed fees are imposed for capturing state-protected species from the wild. For example, the fee for a giant panda is set at RMB 100,000 (US\$13,000). Businesses with authorization to use, sell, or procure state-protected Category I and II species must pay $8 \%$ and $6 \%$ respectively of the sales revenue to the state. $^{22}$ The notice on fees imposed on wildlife import and export distinguishes collection standards between artificially bred species and species from the wild in addition to different fees on species in different protection categories. For example, the state imposes a $7 \%$ fee on the export revenues of stateprotected Category I species caught from the wild whereas the fee is $3 \%$ on the same species artificially farmed.

\section{Penalties for Wildlife Protection Law violations}

Legal penalties for violations of the Wildlife Protection Law come from several sources of laws, legislative decisions, and court rulings. These include the Criminal Code (1997), the Customs Law (2000), the 1988 National People's Congress decision on cracking down upon illegal trafficking in, smuggling of, and profiteering from wildlife products, the Supreme People's Court notice on cracking down upon panda killing and panda pelt smuggling crimes (1987), and the Supreme People's Court interpretation on issues concerning the methods of handling criminal cases involving wildlife resources (2000). Administrative regulations such as the Regulations for Suppressing Crimes Affecting Public Security (1994), State Planning and Economic Commissions' Notice on the Production and Sales of Hunting Rifles (1980), and the 2001 Standards for Managing and Determining Criminal Cases Involving Terrestrial Wildlife Species are also relevant for determining the severity and punishment of the violations. Provisions of these laws, rulings, decisions, and administrative orders provide the legal basis for penalizing violations against the Wildlife Protection Law.

The Wildlife Protection Law therefore contains detailed provisions on penalties for various offenses. These offenses include illegal trade, trafficking, smuggling of protected species, falsification of documents, and use of banned hunting gear and hunting methods. The offenses are divided into three categories: serious offense, very serious offense, and extremely serious offense. Serious offense involves the hunting of five locally protected species or one Category I or three Category II state-protected species at times banning hunting, in areas banning hunting, or using banned hunting gear. In addition, use of banned weapons 10 times or more, setting of traps numbering 500 or more, or digging 100 or more pitfalls could qualify as a serious offense. Very serious offense, however, involves the hunting of 15 or more locally protected species or three Category I or five Category II state-protected species, use of banned hunting gear 20 times or more, setting of traps numbering 1,000 or more, or digging 200 or more pitfalls. Hunting of 30 or more locally protected species or five Category I or seven Category II stateprotected species, setting 2000 or more traps, and digging 300 or more pitfalls would qualify as an extremely serious case. Similarly, illegal sales and purchase of one, two, and three Category I and three, six, 12 Category II state-protected species would qualify as serious, very serious, and extremely serious criminal cases. The severity of the cases is also determined by the sales amount. ${ }^{23}$ 
Based on case severity, perpetrators could face penalties ranging from a 15-day detention to the death penalty. The following table summarizes the offenses, level of severity, likely penalties, and the applicable laws.

In summary, the Wildlife Protection Law, the administrative measures, orders, notices, regulations, and court rulings form a comprehensive legal system regulating activities impacting China's wildlife. This system defines the scope of protection, clarifies rewards and penalties, and implements a fee collection mechanism to inflate the cost of wildlife-related businesses and to deter violations. Wildlife administrations and other law enforcement agencies particularly the forestry police should have checked widespread violations of the Wildlife Protection Law. In reality, enforcement of the Wildlife Protection Law has paradoxically accompanied the worst survival crisis faced by China's wildlife.

Table 1. Offenses, severity of violations, and penalties

\begin{tabular}{|llll|}
\hline Offense & Level of severity & Penalties & Sources of law \\
\hline $\begin{array}{l}\text { Illegal hunting, use of banned } \\
\text { hunting gear, devastation of } \\
\text { rare and other wildlife } \\
\text { resources }\end{array}$ & Serious offense & Up to 3 years' imprisonment & Art. 341, Criminal Code \\
& Very serious offense & Up to 10 years' imprisonment & Art. 341, Criminal Code \\
& $\begin{array}{l}\text { Extremely serious } \\
\text { offense }\end{array}$ & $\begin{array}{l}10 \text { years' to life imprisonment } \\
\text { or death }\end{array}$ & $\begin{array}{l}\text { NPC Decision on Strictly } \\
\text { Cracking down on Serious } \\
\text { Crimes against the }\end{array}$ \\
& & & Economy \\
$\begin{array}{l}\text { Smuggling and profiteering in } \\
\text { wildlife and products }\end{array}$ & Serious offense & Up to 3 years' imprisonment & Criminal Code \\
$\begin{array}{l}\text { Falsification of documents } \\
\begin{array}{l}\text { Impairment of public } \\
\text { security (illegal possession } \\
\text { and carrying of guns and } \\
\text { ammunition) }\end{array}\end{array}$ & Serious offense & Up to 3 years' imprisonment & Criminal Code \\
\hline
\end{tabular}

\section{The Wildlife Protection Law and enforcement challenges}

Xu Gang, a wildlife protection activist, chronicled China's wildlife crisis between 1989 and 1997. He exposed the senseless killing of 16 Asiatic elephants (1995), the smuggling of 22 monitors and 17 pangolins (1995), and indiscriminate hunting in South China's forests by a 60-man hunting squad (1995). Other shocking incidents $\mathrm{Xu}$ documented include the illegal hunting of two Siberian tigers (1993), 60 snow leopards, 118 elks, 1,800 Tibetan antelopes, and 2,000 other Category I and II state-protected species. $^{24}$

Government investigations since 1989 confirmed the crisis. In a 1999 survey of wildlife use in the catering business conducted in 16 provinces by the State Forestry Bureau's (SFB) Wildlife Protection Department (WPD) and the China Wildlife Conservation Association (CWCA), 49.8\% of the 1,381 restaurants, 41.7\% of the 91 markets, and $15.4 \%$ of the food stores investigated were dealing in wildlife products. Yet, only $35.2 \%$ of the restaurants, $6.8 \%$ of the food stores, and $28.6 \%$ of the markets and sellers had licenses to 
deal in wildlife. Of the 53 wildlife species found, 14 of them were state-protected animals accounting for $26.4 \%$ of the total. Except for spotted deer, ostrich, civet cats, blue peacocks, quails, and tiger frogs that were artificially bred, 46 of the species came from the wild. ${ }^{25}$ In an emergency investigation of selected markets in June 2003 following the SARS outbreak, the government seized some 10,000 wildlife animals many of which were state-protected species ${ }^{26}$ In 2004, the State Forestry Bureau released the findings of China's first nationwide wildlife resource investigation, which confirmed the need for urgent rescue of a large number of species. A State Forestry Bureau official admitted that commercial exploitation was pushing many species to the brink of extinction. ${ }^{27}$

What has gone wrong? Why has the Wildlife Protection Law, given its detailed stipulations on the management, protection, and penalty mechanisms, failed to protect the nation's wildlife? Critics in China are of the opinion that the Wildlife Protection Law contains provisions that are self-defeating. To evaluate the claims of the Chinese critics, let us review each one of their arguments.

\section{Protection or utilization}

Chinese critics believed that mission confusion was the biggest problem with the Wildlife Protection Law. Articles 1 and 4 of chapter I present a strange combination of two odd objectives, namely protection and utilization:

Article 1. This Law is formulated for the purpose of protecting wildlife species that are rare or near extinction, protecting, developing, and rationally utilizing wildlife resources and maintaining ecological balance (emphasis added). Article 4. The State shall pursue a policy of strengthening wildlife resource protection, actively domesticating and breeding wildlife species, rationally developing and utilizing wildlife resources, and encouraging scientific research on wildlife (emphasis added).

Article 1 did mention ecological balance as one of the law's objectives. Yet, as critics have pointed out, the most important objective of the law is wildlife utilization. Protection is, therefore, the means for achieving the end of human utilization. ${ }^{28}$

Admittedly, this "protection for human use" objective is not unique to China's Wildlife Protection Law. A quick review of wildlife-related laws of other nations with a tradition of wildlife use reveals similar language. For example, Brazil's animal protection law was drafted with sustainable use of wildlife as one of the objectives. However, the uniqueness of the Wildlife Protection Law is the dominance of the "human use" proposition throughout the legal document. The phrase "wildlife resources" appears eight times in the law while "maintaining ecological balance" is mentioned only once. Besides, "use of wildlife," "wildlife farming and breeding," and "reasonable use of wildlife resources" are the main themes of Articles 1, 2, 4, $5,6,9,17$, and 22 and of the chapter titled "Relevant Legal Articles." Article 17 goes even further by declaring that "the state encourages breeding and farming of wildlife animals."

The contradictory missions have been questioned by Chinese critics. Mang Pin, a scholar on animal welfare issues, challenges the purpose of the Wildlife Protection Law critically:

In ... the Wildlife Protection Law, wildlife species are solemnly proclaimed to be "wildlife resources." Such "resources" are therefore not different from mineral resources or land resources and are therefore nothing special. Implicit and evident in this positioning of the wildlife as resources is the belief that wildlife exist for humans and are a resource to be used by the humans. ... Human use is the essence of the law. The purpose of the Wildlife Protection Law is to define how the resources are to be "used." This is why the protection for human use proposition has been widely accepted in China. ${ }^{29}$ 
To Chinese critics, the "protection for human use" proposition undercuts law enforcement and leads to practices that compromise wildlife protection. According to Li Xiaoxi, professor, People's Congress deputy, and a long-time animal advocate, the protection for human use proposition has not only made enforcement of the Wildlife Protection Law difficult, it has also undermined China's ability to fulfill its Convention on International Trade of Endangered Species obligations in curbing global trade in endangered species. ${ }^{30}$ Zhang Endi, a professor and board member on the World Wildlife Conservation Council, questioned the alleged conservation objective of wildlife farming. The "orderly use of wildlife resources" proposition, he argues, contradicts the objective of wildlife protection. Farming wildlife, he argues, does not equate with protecting wildlife. ${ }^{31}$ According to Chinese critics, the classification of wildlife as a natural resource undermines the objective of protection.

\section{Protected versus unprotected species}

Critics of the Wildlife Protection Law also highlight two issues related to its list of protected species. First, the list is believed to be outdated. It does not reflect the new situation faced by the nation's wildlife. The original protection list of the Wildlife Protection Law included 410 species grouped under Category I (109 species), that is, the most endangered, and Category II (301 species), the fairly endangered species. ${ }^{32}$ However, China's wildlife crisis has deepened since enactment of the Wildlife Protection Law. In 1997, in an area of the Tibetan Plateau, covering $4,000 \mathrm{~km} 2$, a foreign scientist spotted three Tibetan antelopes only, whereas he had observed 1,200 in the early 1990s. ${ }^{33}$ Many other species have not fared better as Table 2 shows.

Expanding the protection list or elevating species from Category II to Category I is easier said than done. Critics worry that the inclusion of one species could constitute a disservice to that species. In other words, the identification of a new endangered species could attract wildlife traders and lead to its extinction faster. In South China, wildlife eating is a thriving business. It has also become a status symbol for the new rich. "Driven by this vainglory, when one brags about having eaten a Category II species, others would try to outdo him by eating a Category I species." ${ }^{34}$ Despite the concern just stated, proponents of Wild Protection Law revision agree that the protection list should reflect the changes in China's wildlife situation.

Table 2 Selected species population before and after WPL enactment

\begin{tabular}{|llll|}
\hline Species & Protection Category & Population before WPL & Population after WPL \\
\hline Musk deer & $\mathrm{I}$ & $1665(1985)$ & $100(1996)$ \\
Long-armed black gorilla & $\mathrm{I}$ & $2000(1970 \mathrm{~s})$ & $19(2000)$ \\
Chinese river dolphin & $\mathrm{I}$ & $187(1985-1987)$ & $5(1999)$ \\
Wild camels & $\mathrm{I}$ & $3000(1980 \mathrm{~s})$ & $800(2003)$ \\
Tibetan black bears & $\mathrm{II}$ & $14,000(1995)$ & $7,000(2005)$ \\
\hline
\end{tabular}

Source: Relevant articles in Chinese Wildlife 24, no. 4 (2003): 4-5, 24; Chinese Wildlife 24, no. 5 (2003): 28-30; Chinese Wildlife 26, no. 1 (2005): 18-19, 27.

A second issue deals with the status of the protected species in captivity. Admittedly, in coverage, the Chinese Wildlife Protection Law does not differ from similar laws in other countries such as the US Endangered Species Act (1973). Yet, in the view of Chinese critics, silence in the Wildlife Protection Law on the protected species in captivity is a problem. Whereas wildlife animals in institutionalized settings in many other countries are protected under a comprehensive welfare law or other special laws, protected species in captivity in China are either not protected at all or their protection is minimal under separate 
regulations. Consequently, as Chinese critics point out, this silence indirectly encourages illegal hunting of the protected species and their conversion into captive animals. Today, the protected species lose their protection status once they are placed in captivity.

\section{Local or national responsibility?}

Article 14 of chapter II (Protection of Wildlife) stipulates that "local governments shall provide compensation for damages to agricultural produce or for any other damages caused by protecting the state- or locally-protected species" and that "the methods of compensation shall be determined by the provincial, autonomous region, and municipality governments." The consequences of this stipulation are apparent. Without funding from the national government, local governments are the only financial source for protection activities. Not surprisingly, wildlife protection is most urgent in economically backward regions. Local governments in these regions are the most strapped for funds. Because of funding shortages, damage to crops in nature reserves is often delayed or not paid in full; compensation payment for damage to crops outside the reserves is not made at all. ${ }^{35}$ To raise money, local authorities resort to measures that compromise the objective of protection.

According to a recent media report, China's northwestern provinces of Qinghai, Xinjiang, Tibet, and Ningxia are opening hunting sites to foreigners. Fees collected are reportedly to be used for wildlife protection. ${ }^{36}$ In Anhui, where endangered Chinese alligators are artificially bred for conservation purposes, its conservation center has been opened as a tourist attraction. Two local restaurants are authorized by the CWCA to serve delicacies made with Chinese alligator meat. Some of the alligators have even been sold to restaurants in nearby Jiangxi. ${ }^{37}$ Wildlife parks, the so-called training ground for returning endangered species such as Siberian tigers back to their natural habitats, are run as commercial enterprises.

"The national government cannot hand important protection responsibilities over to the local governments," Mang Pin argues. "In so doing, it is shirking its responsibility." If the national government establishes a nature reserve, it should invest in it. ${ }^{38}$ Other scholars proposed the creation of a special wildlife protection fund. The national government should be the principal financial contributor. Moreover, it is the national government that should compensate businesses or individuals whose interests are impacted by wildlife protection. It is unfair, they continue, for the local authorities to shoulder the compensation expenses. ${ }^{39}$ Local shortage of funding has undercut local ability to fulfill the compensation duty. In Yunnan, compensations to the farmers are shared by the provincial and the subprovincial authorities. In Nanpin township which is frequented by the protected Asiatic elephants, damage caused by the elephants amounted to RMB 2.6 million between 1996 and 1999. Yet, according to Aster Zhang, former China director of the International Fund of Animal Welfare (IFAW), the township was only compensated RMB 14,000, averaging a few renminbi per affected person. ${ }^{40}$

Similar problems also exist nationwide. Frustrated peasants often resort to extreme measures to protect their interests. In Jiangxi, a peasant was arrested for electrocuting protected wildlife animals to death. In Zhejiang, vegetable farmers set up sticky nets to ward off birds from their expensive seasonal greens. Li Yumin, a State Forestry Bureau official, proposed that wildlife compensations should be part of the state budget for handling natural disasters. ${ }^{41}$

\section{Politics and enforcement challenges}

The failure of the Wildlife Protection Law is hardly surprising. Its enforcement does not differ from that of most other Chinese laws, particularly environmental protection laws. In addition to the problems of the law 
itself, the Wildlife Protection Law's failure to deter violations has also been affected by the reform politics and China's current state system.

\section{Institutional obstacles}

In her study of China's environmental mismanagement, Elizabeth Economy identifies several obstacles to China's environmental governance. These include vague environmental laws that give local officials great leeway in interpretation; diffusion and overlapping of protection responsibilities among different agencies; weak institutional standing of the environmental protection agencies particularly those at the local level; shortage of funding, lack of adequate and qualified personnel; and governmental interference in judicial decisions. ${ }^{42}$ Wildlife protection suffers from similar institutional malaise.

At the national level, the Wildlife Protection Department under the State Forestry Bureau is directly responsible for managing the nation's wildlife. Yet, the former is only one of the nine functional departments in the latter. While the national Wildlife Protection Department supervises the wildlife protection work of its provincial counterparts, it exercises no organizational power over them. Provincial wildlife protection departments are beholden to the local officials who decide on their budget and staff needs and who care more about local growth. Wildlife protection departments often find that their law enforcement efforts meet with resistance from local authorities and from work units that have the use right of the land and the "resources" on the land. In other words, wildlife protection departments can raise the issue of Wildlife Protection Law violation. Their voices are often ignored because they cannot stop the businesses or organizations from doing what they are doing since the latter group of actors have the use right of the land.

Citing a US legal case involving the New York State Environmental Bureau and Sour Mountain Real Estate, Wang Xiaogang argues that China's wildlife protection departments at all levels should have the power to curb the use right of the land out of the need to protect the public interest or public property, that is, the habitat of the endangered species or protected species. He argues that use right of state land should be revoked, when necessary, by building nature reserves. And to protect wildlife conceived as public interest or public property, the government should exercise the power to restrict individual property rights. $^{43}$

The weak institutional standing of China's wildlife protection departments is most clearly indicated by their small budget and inadequate staff. There is no national budget for wildlife protection. And, county-level protection offices are outside local government budgets. ${ }^{44}$ The operation of protection offices at the grassroots level is mostly sustained by fees and fines. ${ }^{45}$ In Shanghai, wildlife protection is not part of the government planning for future social and economic development. It is therefore not a consideration in budget proposals. ${ }^{46}$ Not surprisingly, staffing needs of wildlife protection are generally ignored. In 2004 , China had 2,194 nature reserves covering 148 million hectares of land, $14.8 \%$ of the Chinese territory. ${ }^{47}$ Yet, only 28,392 staff were employed to run these nature reserves, on average 12.9 workers for each reserve. For example, Xinjiang's Aerjin Mountain Nature Reserve, built in 1985 and covering 45,000 km² (bigger than Taiwan), was under the supervision of a husband-and-wife team. The couple patrolled an area of 7 to $8 \mathrm{~km}^{2}$ a day. ${ }^{48}$ Lack of funding also explains the severe shortage of experts and researchers in wildlife protection. ${ }^{49}$

Government interference in judicial decisions is by no means hearsay in wildlife-related cases. China's court system is not an independent branch of the Chinese government. It depends on the executive arm of the government for budget and personnel, thus allowing the government to sway its decisions. ${ }^{50}$ In China, $70 \%$ of the cases involving Wildlife Protection Law violations by catering businesses took place in Guangdong before the SARS outbreak. Yet, as of 1999, five individuals had been condemned to death 
while 10 others were sentenced to imprisonment. ${ }^{51}$ And, in 1999, 236 trafficking cases involving protected species were handled by China's courts. Out of this number, 42 of them were serious and extremely serious cases. However, the courts only detained 15 suspects. Of the 15 detainees, 11 received light sentences while four others were set free. ${ }^{52}$

\section{Economic growth and cadre career mobility}

One of the important objectives of reform is to promote productivity. The focus of the Party's cadre evaluation criteria was therefore changed from ideological conformity to economic growth. The ability to facilitate growth, attract investment, create jobs, and generate revenue became important criteria of cadre appraisal. ${ }^{53}$

Local growth has a direct link to the career mobility of the local leaders. ${ }^{54}$ The career mobility of Zhao Zhiyang (Party Secretary of Sichuan) and Wan Li (Party Secretary of Anhui) in the early 1980s was enhanced by the bold reform measures they implemented in their respective provinces. Similarly, Zhu Rongji's promotion to premiership had a lot to do with his supervision of Shanghai's phenomenal growth in the early 1990s. These erstwhile provincial leaders were not promoted to the Party center because of education development or environmental protection. Their promotion was exclusively based on economic performance.

Studies of China's reform and the new cadre evaluation policy have identified many of their drawbacks. ${ }^{55}$ Local authorities are reluctant to divert funds to programs producing no direct economic gains. ${ }^{56}$ In Sichuan's Baoding Wildlife Reservation, for example, local officials reportedly failed to compensate peasants who suffered damages caused by the protected species. The number of compensation cases reportedly increased from seven in 2000, to 12 in 2001, and 20 in 2002. ${ }^{57}$ Spending money on protecting the endangered species, in the eyes of local officials, would divert funds from productive activities. Despite recent central government emphasis on the need to balance growth with environmental protection, local leaders are still not motivated to address environmental issues. As critics point out, some local officials would not hesitate to spend large sums of money on "showcase projects" for the inspection of their superiors, while complaining about shortage of funds for wildlife protection. ${ }^{58}$

\section{Shortage of funds}

The shortage of funds impedes wildlife protection. Two factors contribute to the shortage. First, no separate budget for wildlife protection exists at the national or provincial level. Funding for wildlife protection comes from the budget of the state or provincial forestry bureaus or other relevant agencies. Funding for special projects required by the Wildlife Protection Law is granted on a case-by-case basis by the national treasury. For example, the Finance Ministry earmarked special funding for the four-year nationwide survey of China's wildlife in 1995. Second, local governments are reluctant to spend on nonproductive activities. According to one study, China's 32 provinces spent altogether US $\$ 10$ million in wildlife protection in 1999. On average, the share of each province was only US\$310,000. In contrast, the US expenditure on wildlife protection in the late 1970 s was already US\$700 million, some 150 times that of mainland Chinese spending. ${ }^{59}$

Shortage of funds has delayed institution building and Wildlife Protection Law enforcement. Today, 80\% of the county and city governments in the country have not set up wildlife protection offices. ${ }^{60}$ Many of the 50 -odd national nature reserves exist in name only because of shortage of funds. ${ }^{61}$ Local nature reserves are most impacted by such a shortage. Sichuan's Tiebu Nature Reserve was so underfunded that it could not satisfy the most basic needs of the employees. A pair of binoculars was the reserve's only 
equipment. ${ }^{62}$ Xinjiang's Aerjing Nature Reserve was so strapped for funds that one semiautomatic rifle, a $\mathrm{dog}$, and a flashlight were all the equipment the husband-and-wife team had. ${ }^{63}$

Lack of funding is also blamed for research impairment and compromised protection work. ${ }^{64}$ Of the funding for a four-year nationwide wildlife survey in the mid-1990s that was to be contributed by provincial governments, $40 \%$ had not materialized. What was most affected was Wildlife Protection Law enforcement. Lack of funding has made the forestry police the poorest equipped and most understaffed arm of China's police force. Their equipment, communications capabilities, and transport vehicles, particularly in Yunnan and the Qinghai-Tibetan Plateau, cannot match those of the transnational poachers, thus undermining the forestry police's ability to enforce the Wildlife Protection Law. ${ }^{65}$ Funding shortage made it hard for the forestry police to conduct around-the-clock patrols in the vast regions where, for example, Tibetan antelopes live. For a long time, the protection of Tibetan antelopes was carried out by volunteers.

\section{Local protectionism}

To encourage development using local resources, Deng Xiaoping called on provincial leaders to make good use of local conditions. ${ }^{66}$ Since both the national constitution and the Wildlife Protection Law sanction "reasonable use of the natural resources," of which wildlife is a part, wild animals have been used in many provinces as a revenue-generating resource for local development. The Wildlife Protection Law's "reasonable use" policy therefore justifies local use of the wildlife "resources." Local governments have stood behind such a commercial activity.

\section{Wildlife farming}

China's wildlife farming started in the 1950s. By the end of the 1970s, 3,000 breeding farms had been set up raising hundreds of thousands of minks, for example. At the same time, there were nearly 100 farms breeding some 400,000 deer. China's wildlife farming was expanded in the 1980s when private individuals entered the formerly state-monopolized production. By the early 1990s, wildlife breeding included bears, Siberian tigers, Chinese alligators, wild horses, and others. Altogether, 40 wildlife species had been artificially bred. ${ }^{67}$ In 2003 , the State Forestry Bureau announced that China had succeeded in commercially farming 54 wildlife species. ${ }^{68}$

Wildlife breeding is an economic enterprise despite the alleged conservation objective. In 1998, it was estimated that people directly employed in wildlife farming numbered more than $100,000 .^{69}$ In 2003 , Sichuan Province alone had as many as 10,000 employed in bear bile production. ${ }^{70}$ In Northeast China's Jilin and Heilongjiang, wildlife farming continues to thrive at a time when both provinces are dealing with large numbers of laid-off workers. In Jilin, annual cropping of pilose antlers in 1998 amounted to RMB 500 million, the sixth biggest industry of the province. Its share in the revenue of Changchun, the provincial capital, was even bigger. ${ }^{71}$ Similarly, Heilongjiang's bear farming has grown rapidly since the mid-1990s. Heibao Pharmaceutical Company boasts the world's biggest bear farming operation with more than 1,000 Asiatic bears bred for bile extraction. As a major taxpayer, the company attracts visitors from both the central and local governments. ${ }^{72}$ In early 2006, there were some 70 bear farms across the country. They produce some 12 tons of bear bile a year with a total market value of RMB 8 billion. ${ }^{73}$

As the wildlife farming industry grows, so does the number of runaway wildlife that end up being eaten across the country. Reports in the wake of the SARS outbreak disclosed that 600 farms raising civet cats dotted the countryside in Canton, Hunan, Guangxi, and other southern provinces. These farms supply artificially bred civet cats to thousands of restaurants in Guangdong and elsewhere. Wildlife eating has been a tourist attraction. In Guangdong, 20 tons of live snakes and 20,000 birds were reportedly 
consumed every day in pre-SARS days. Rare turtles and other reptiles are also consumed daily in large quantities. ${ }^{74}$ Local officials regard wildlife eating and wildlife farming as sources of revenue. According to one source, China's wildlife breeding industry is worth RMB 100 billion annually. ${ }^{75}$ It provides employment in farming, transport, trading, and retail businesses. Moreover, the industry is also believed to contribute to social stability because of job creation, an overriding concern of the Chinese government at all levels. What local officials refuse to see is that wildlife animals caught in the wild are often sold as farmed animals.

\section{Wildlife trade}

For the central and local governments in particular, the wildlife trade generates revenue. When the Wildlife Protection Law was first implemented, China exported US\$200 million worth of wildlife products. Processing wildlife products for export is considerably low in cost but with handsome returns in profit. $^{76}$ Northwestern China's Shanxi Province, for example, has long been a fur-exporting province. It exports as many as 100,000 pelts annually. The motivation to increase pelt export has been great since China decentralized control over foreign trade. ${ }^{77}$ In 2000, China's total export value of wildlife products amounted to US\$364 million. ${ }^{78}$ In 1986 , China only had one port, namely Tianjin, for handling wildlife export business. However since then, the number of such ports has increased to six. ${ }^{79}$ In 2000, 10 cities reportedly had authorization to handle wildlife exports. ${ }^{80}$ Local competition for profits in wildlife trade explains this increase in the number of export ports.

Local protectionism further stimulates wildlife trade. In 1990, Liaoning exported 2.72 tons of bear paws. In the same year, a government trading firm in Beijing shipped five tons of Mongolian gazelles to the international markets. Reportedly, customs did not even question the legality of the export products made from state-protected Category II species. ${ }^{81}$ Following the SARS outbreak, Chinese authorities launched the biggest nationwide investigation into the wildlife trade in the summer of 2003 . The findings were shocking. As many as 838,500 endangered species were identified from 14,900 animal fairs and 67,800 restaurants. ${ }^{82}$

Local protectionism hinders China's fulfillment of its Convention on International Trade of Endangered Species obligations. In early 2004, Russian customs confiscated 800 pairs of bear paws bound for China. ${ }^{83}$ More than 500 species in Russia are believed to be coveted by Chinese wildlife traders. ${ }^{84}$ In recent years, wild bears caught in Burma have reportedly been smuggled into China to replenish bear farms in China's Yunnan Province. Endangered species, such as pythons, monitors, pangolins, turtles, and snakes, are imported in large quantities from Vietnam and other Southeast Asian countries to supply restaurants and hotels in Guangzhou and elsewhere. ${ }^{85}$

The lure of profits constitutes a big diversion for the officials from their responsibility to enforce the Wildlife Protection Law. Some local officials even openly entertain the idea of using the wildlife trade as a way to boost local development. Quoting from an article in Chinese Wildlife:

Some local officials are unworthy of their official titles. They have not studied in earnest the state's relevant laws on wildlife protection. Not only are they indifferent to the need for wildlife protection, they are also short-sighted in believing that wildlife business is a lowcost, high-yield operation that can be used to promote local growth and attract eaters and business people as well as to contribute to the local restaurant business, tourism, and economy in general. ${ }^{86}$

Blaming local officials for being "short-sighted," incompetent, and ignorant of state laws misses the real target. Most local leaders are rational actors whose stake in economic growth is intertwined with their 
career and personal advancement. They may be sincerely concerned with the disadvantaged in society when they say, "Some people are hungry. Where can we have money for wildlife protection? Are people more important or animals?" 87 They act more, in the words of Elizabeth Economy, in response to the political economy at the local level. Local officials can be intimately connected with local businesses. They may even be partners of local business owners. Not only does local growth promote their career mobility, it also adds to their personal wealth. Little wonder that local environmental officials face pressure from local leaders whose primary concern is economic growth rate. ${ }^{88}$

\section{Wildlife protection: legislative and political solutions}

The Wildlife Protection Law cannot stand as it is today. A major overhaul of the law is long overdue. Yet, changes in legislation alone do not improve the prospects of enforcement. Actions in the political arena are more fundamental to China's environmental governance in the long run.

\section{Wildlife Protection Law objectives}

The "protection for human use" objective of the Wildlife Protection Law should be dropped. Industry and government opponents to revision of the Wildlife Protection Law will definitely object to the removal of this utilitarian objective. Yet, dropping the "protection for human use" goal is not unattainable. Nor is it detrimental to China's economic interests and political stability. The government's ban in 1993 on tiger and rhinoceros trade offers a good example of the central authorities acting as a forceful enforcer. If a ban can be imposed on tiger and rhino trade, the government should also be able to enforce the Wildlife Protection Law.

Loss of jobs and of revenue is a major argument of the opponents against discarding the "human use" objective. Yet, China's export of wildlife (including wild plant) products earned US\$300 million in 2000. Its share in China's total export was less than $0.16 \%$. Bear farming's annual output of RMB 8 billion (approximately US\$1 billion) accounts for an insignificant portion (about $0.01 \%$ ) of China's annual GDP of US\$1 trillion (China's official figure of its economic size). Admittedly, closing all bear farms, for example, could cause job loss in locations such as northeast China, Sichuan, Yunnan, Shanxi, Fujian, and other places. The assertion of its adverse impact on social stability nationwide is an exaggeration. Ending wildlife farming can be approached in phases to facilitate transition to alternative kinds of production.

Abandoning the "protection for human use" objective and suspending wildlife farming would actually foster China's trade relations with the outside world. Chinese traditional medicine (CTM), particularly prescriptions with wildlife parts, is yet to go through rigorous clinical trials and tests. A recent report disclosed that global Chinese traditional medicine sales amounted to US\$16.5 billion. China's share of the sales was only about $5 \%$. And, imported Chinese traditional medicine occupied one-fifth of the mainland Chinese market. Experts attributed China's small worldwide market share to problems such as unsubstantiated healing claims, serious side-effects, and poisonous residues. ${ }^{89}$ Reliance on wildlife parts in Chinese traditional medicine prescriptions also impedes their export. European Union consumers, who are rejecting eggs from hens raised in battery cages, ${ }^{90}$ are likely to boycott Chinese traditional medicine products that contain parts from cruelly farmed wildlife species. According to a survey of European Union consumers, $20 \%$ of the male and $48 \%$ of the female respondents expressed reluctance to use Chinese traditional medicine because of ingredients from endangered species. Moreover, a significant number of the respondents avoided Chinese traditional medicine because of cruelty to bears, deer, rhinoceros, seals, and tigers. ${ }^{91}$

Then what should be the new point of departure for the Wildlife Protection Law? Liang Congjie, head of the nongovernmental Friends of Nature group, called for a "breakthrough" in thinking. He proposed 
positioning China's wildlife protection policy on the principle of "ecological balance first." ${ }^{92}$ A scholar, Liu Wenyan, even questioned the philosophical basis of the "protection for human use" idea. Liu contends that wildlife species have their own value of existence independent of human interests. Summarizing the views of the Chinese opponents of "protection for human use," Liu calls for balancing human needs and the ecological needs as the new guiding principle. ${ }^{93}$

\section{Defining wildlife species}

Defining the wildlife species in the Wildlife Protection Law has received much attention since the outbreak of SARS. ${ }^{94}$ Two sets of distinctions are believed to be necessary. First, the Wildlife Protection Law should distinguish between endangered species in the wild and those in captivity. This will serve to protect the animals in the wild as well as establish important welfare standards for institutionalized wild animals. ${ }^{95}$

A second important distinction should be made between the endangered species and the not-yetendangered species. Specifically, the Wildlife Protection Law should include articles on the protection measures and penalties for exploitative use of the not-yet-endangered species. Without concrete protection measures for the latter group of animals, proponents of Wildlife Protection Law revision fear that endangered species could continue to be shipped out of the country or traded domestically under the guise of unprotected species. The current list of protected species should be expanded to reflect the wildlife situation at the present time. As Liang Chongjie pointed out in his legislative proposal to the National People's Congress, the Wildlife Protection Law cannot limit state protection to the rare and endangered species only. State protection should be extended to other wildlife species that are currently not protected such as sparrows, different species of frogs, and other reptiles. ${ }^{96}$

\section{Animal welfare}

The inclusion of anticruelty articles in the Wildlife Protection Law is advocated by Chinese critics. As the first law professor teaching animal welfare laws in China, Song Wei supports the introduction of minimum welfare standards as implemented in the EU countries. These standards, the so-called "Five Freedoms," outlaw conditions that subject animals to pain, suffering, severe space deficit, food deprivation, and behavioral abnormality. He believes that penalties for violation of the minimum requirements should be written into the Wildlife Protection Law or other special welfare laws. Another scholar proposes the provision of anticruelty clauses in the Wildlife Protection Law so that the law can classify harm done to wildlife species into two categories: intentional harm and negligent harm. Furthermore, such harm should be categorized into that with grievous and that with minor consequences.

Another view supports the drafting of a comprehensive animal welfare law, ${ }^{97}$ which is favored by most animal advocates and legal experts. Yet, it is also most resisted by the business interests and frowned on by government officials. In early 2004, a Beijing municipal government's draft of animal welfare law relating to lab animals was forced to be withdrawn only a few days after it was published on a government web site. ${ }^{98}$ The concern of the opposing officials and scholars was the level of difficulty in enforcing the law and the resulting damage to the integrity of the city's laws. The proposal of a comprehensive animal welfare law, to Chinese officials in August 2004, was too progressive and too early for China. ${ }^{99}$ In view of the current resistance to comprehensive animal welfare legislation, the Wildlife Protection Law should be the place to include anticruelty provisions.

\section{Financial input from the central government}

As discussed earlier, local governments have no incentive to fund nonproductive activities. Worse still, damage caused by the protected species often takes place in economically underdeveloped parts of the country. Local governments in these regions are already financially strapped. Chinese critics argue that it 
is "unreasonable and unrealistic for the local authorities to shoulder the bulk of the expenditure for wildlife protection." They recommend that the Wildlife Protection Law should provide for special funds for wildlife protection. The use of the money should be judged in accordance with the specific situations where the damage is incurred. A compensation mechanism-with the central government responsible for most of the damages-should be established. ${ }^{100}$ The special funds can also be used for handling emergency situations such as SARS and the bird flu outbreak.

State special funding serves other important objectives. It will help to provide for the creation of a specialized rank of officials for wildlife protection and also to fund nature reserve management. Furthermore, it will eliminate the need for conservation institutions to exploit the objects of protection to finance their operation. Wildlife protection cannot act as a player in the market economy.

\section{Legislative and political openness}

Until very recently, China's law making was a highly exclusive state prerogative. Political considerations in the reform era have dominated China's legislative process. The enactment of the Wildlife Protection Law in the late 1980s was a typical case of legislation with minimum societal input. Little wonder that the Wildlife Protection Law gives full representation to the views and positions of the nation's wildlife administrations, business interests, and local governments. In the 1980s, unofficial groups in China began to emerge, but their voice was barely audible. The recent public hearings held by Guangdong's and Beijing's local legislatures on the fate of the former's wildlife trade and the latter's animal welfare law were encouraging steps. Is China's national legislature ready to adopt the same approach to legislation?

Legislative openness in China ultimately hinges on political liberalization. Today, grass-roots environmental groups continue to operate with difficulty. The government precludes the formation of such groupings through a strenuous registration process. Any groups formed are placed under a government agency to allow for state control and supervision. Environmental groups are warned against political activism and penalized for failure to stay clear of politics. ${ }^{101}$ Chinese activists, particularly those who are versed in the politics of contemporary China, are extremely cautious not to get involved in controversies that could cause government reprisal and lead to a reversal of what has already been accomplished ${ }^{102} \mathrm{~A}$ recent proposal by a Beijing activist on the need to revise the Wildlife Protection Law exhibits a high level of reason, a positive outlook, and it provides constructive suggestions. The proposal is less a criticism of China's legislative apathy than a whole-hearted support for the national legislature to take bolder actions in the interest of the nation.

Despite the moderate advocacy of the activists, the Chinese authorities are not ready to open policymaking to the society. As China's prominent environmental activists have pointed out, "without real democracy there can be no everlasting green hills and clear waters." ${ }^{103}$ The same argument can be made that China's wildlife protection will remain an uphill struggle if political liberalization continues to be postponed.

\section{Conclusions}

China's wildlife protection remains a daunting task. In the prereform era, wildlife was managed as a natural resource. Policymaking was largely reactive in nature. The policy objectives ranged from establishing state authority in wildlife management, regulating hunting and fishing behaviors to forest protection, and curbing indiscriminate hunting in times of national crisis (1960-2). While 19 nature reserves had been established by 1965, the post-Mao Chinese leadership inherited a legacy of neglect in the policy area of wildlife protection. In the last 10 years of Mao's rule, there was a complete void in wildlife policymaking. Despite the policy advocating "protection, domestication, and hunting" and the 
official position that views wildlife as a natural resource, commercial exploitation was a state-monopolized enterprise. Widespread wildlife exploitation by private individuals has not taken place.

The politics of the reform era unleashed Pandora's box in wildlife management. Reform emancipated farm labor and allowed labor surplus into diversified production. Wildlife farming began to take off. The Wildlife Protection Law represented the government's response to the new challenges. Yet, wildlife devastation has worsened since the Wildlife Protection Law enactment. Chinese critics have identified areas that hinder Wildlife Protection Law enforcement. Among the problems, the Wildlife Protection Law's mission confusion emphasizing "reasonable utilization" and its delegation of key responsibilities to local authorities constitute major roadblocks to its enforcement. China's failure to check the downward spiral of the wildlife crisis is more indicative of a political system that is incapable of tackling the challenge. As a postsocialist developmental state, the Chinese authorities will continue to push for growth rather than wildlife protection.

In conclusion, the Wildlife Protection Law does contain provisions undermining its enforcement. However, China's failure in wildlife protection enforcement is more rooted in the current state system. Wildlife protection cannot be left to the devices of local governments. Nor can it be pushed out onto the market as an economic player. Revision to the Wildlife Protection Law is necessary; its revision alone is not sufficient. China's wildlife crisis requires both short-term legislative and long-term political solutions.

\section{Notes}

The author wishes to thank the anonymous reviewers for their feedback and valuable suggestions. Thanks also go to Dr George Jacobs of JF New Paradigm Education in Singapore. His extensive comments on the earlier version of the paper were enormously helpful. Institutional and funding support from the University of Houston-Downtown is gratefully acknowledged.

${ }^{1}$ Emma Ross, "Blood Tests on Market Workers Strengthen SARS Link between Animals and Humans," Associated Press Report, 27 May 2003.

2 Merritt Clifton, "SARS Shuts Live Markets-May Change Chinese Menus," Animal People, 30 June 2003, <http://www.animalpeoplenews.org/03/6/SARSshutsmarkets6.03.html>, accessed 12 July 2006.

${ }^{3}$ Annie Mather, Animals Asia Foundation's media director, who investigated China's wildlife trade, was shocked at the plight of the animals on the market and the extent of illegal wildlife trade in this southern Chinese province. Electronic interview with Annie Mather, Media Director of Animals Asia Foundation, 27 March 2004.

${ }^{4}$ Zheng Yi, Zhongguo zhi huimie: Zhongguo shengtai bengkui jinji baogao (China's ecological winter) (Hong Kong: The Mirror Books, 2001), 235-6.

${ }^{5}$ Ma Jianzhang, "Yi jingji jianshe wei zhongxin, kaichuang woguo yesheng dongwu yangzhiye de xin jumian" (Create a new situation in China's wildlife farming under the banner of economic construction as the national priority), Chinese Wildlife, no. 4 (1992): 12-14.

${ }^{6}$ Hsieh-Yi, Yi-Chiao, Yu Fu, Mark Rissi, and Barbara Maas, "Fun Fur? A Report on the Chinese Fur Industry" (report jointly sponsored by the Swiss Animal Protection SAP, Care for the Wild International, and EAST International, 2005).

${ }^{7}$ China Biodiversity Office, "Executive Summary." The First State Report on China's Execution of the "Convention on Biological Diversity," 1 March <http://www.biodiv.gov.cn/swdyx/145241087982698496/20040301/1046429.shtml>, accessed 2 July 2006.

${ }^{8}$ Information about China's wildlife policymaking in the prereform era is scattered in different sources such as Cai Shouqiu, Huanjing ziyuan faxue jiaocheng (Textbook on environmental and resource 
laws) (Wuhan: Wuhan University Press, 2002), particularly chapter three; and Jing Ruilin, Huanjing faxue (The study of environmental law) (Beijing: Beijing University Press, 2002), also chapter three.

${ }^{9}$ State Council, "Guowuyuan guanyu jiji baohu he heli liyong yesheng dongwu ziyuan de zhishi" (State Council instructions on actively protecting and reasonably using animal resources), 14 September 1962, <http://www.people.com.cn/GB/33831/33836/34143/34234/2551386.html>, accessed 12 July 2006.

${ }^{10}$ Zheng, Zhongguo zhi huimie, 232-3.

11 Judith Shapiro, Mao's War against Nature: Politics and the Environment in Revolutionary China (Cambridge: Cambridge University Press, 2001), 67-94.

${ }^{12}$ Xinhua News Agency, "Shanghai dongwuyuan xiugai shuomingpai 'rou ke shi' 'haishou' deng bei tichu" (Shanghai Zoo revises the information boards to eliminate descriptions such as "flesh can be eaten" and "harmful pests"), 4 March 2004, <http://www.china.org.cn/chinese/TR-c/113746.htm>, accessed 28 July 2006.

${ }^{13}$ State Council, "Guowuyuan guanyu jiji baohu he heli liyong yesheng dongwu ziyuan de zhishi."

14 In 1960-62, government offices, the Chinese military, and individuals were engaged in an unprecedented hunting spree. The Foreign Affairs Ministry, for example, sent hunting teams equipped with machine guns to Inner Mongolia and Northeast China to hunt Mongolian gazelles. One team returned to Beijing with a seven-boxcar load of dead Mongolian gazelles. See the memoir of China's former Defense Minister Geng Biao, Geng Biao huiyi lu: 1949-1992 (Geng Biao remembers: 19491992) (Nanjing: Jiangsu People's Press, 1998), 162-7.

${ }^{15}$ State Council, "Guowuyuan guanyu yange baohu zhengui xiyou yesheng dongwu de tongling" (State Council order on strictly protecting rare and endangered wildlife species), State Council Order no. 62, 1983, <http://vip.chinalawinfo.com/Newlaw2002/SLC/SLC.asp?Db=chl\&Gid=1605>, accessed 20 April 2006.

16 "Woguo yesheng dongwu ziyuan de xianzhuang" (The current state of China's wildlife resources), Chinese Wildlife, no. 3 (1989): 3-4 (no author).

${ }^{17}$ Ibid.

${ }^{18}$ Ibid.

${ }^{19}$ Forestry Ministry and Agriculture Ministry of the People's Republic of China, "Guojia zhongdian baohu yesheng dongwu minglu" (List of wildlife species under state protection), 14 January 1989, <http://vip.chinalawinfo.com/Newlaw2002/SLC/SLC.asp?Db=chl\&Gid=7138>, accessed 2 July 2005.

${ }^{20}$ Forestry Ministry, "Linyebu guanyu hezhun bufen binwei yesheng dongwu wei guojia zhongdian baohu yesheng dongwu de tongzhi" (Notice on approving the inclusion of certain endangered species in the state-protected lists), Forestry Ministry Notice no. 48, 14 April 1993, <http://vip.chinalawinfo.com/Newlaw2002/SLC/SLC.asp?Db=chl\&Gid=9694>, accessed 29 June 2006.

${ }^{21}$ Forestry Bureau, "Guojia baohu de youyi de huozhe you zhongyao jingji, kexue yanjiu jiazhi de lusheng yesheng dongwu minglu" (List of state-protected terrestrial species that are beneficial and of important economic and scientific research value), State Forestry Bureau Order no. 7, 2000, <http://vip.chinalawinfo.com/Newlaw2002/SLC/SLC.asp?Db=chl\&Gid=36047>, accessed 18 June 2006.

${ }^{22}$ Forestry Ministry, Finance Ministry, and State Price Administration, "Lusheng yesheng dongwu ziyuan baohu guanlifei shoufei banfa" (Measures for the collection of administration fees for protecting terrestrial wildlife resources), Forestry Protection Document no. 72, 1992, <http://vip.chinalawinfo.com/Newlaw2002/SLC/SLC.asp?Db=chl\&Gid=15636>, accessed 18 July 2006.

${ }^{23}$ Forestry Ministry and Public Security Ministry, "Guojia linyebu gong'anbu guanyu senlin he lusheng yesheng dongwu xingshi anjian de guanxia ji li'an biaozhun de guiding" (Rules on the standards for managing and starting a criminal investigation of cases involving terrestrial wildlife animals), 1994, 
<http://law.chinalawinfo.com/newlaw2002/SLC/SLC.asp?Db=chl\&Gid=35431>, accessed 18 July 2006.

${ }^{24}$ See Xu Gang, "Zhongguo yesheng dongwu xianzhuang" (The current state of China's wildlife animals), Friends of Nature report, 5 March 1997, <http://cn.greenstone.org/epi/read.php?id=166>, accessed 27 July 2005.

${ }^{25}$ Liu Ping and Su Shugen, "Qing zuixia liuqing" (Please watch what you eat), Chinese Wildlife 22, no. 4 (2001): 28-9.

${ }^{26}$ Yu Hu, "10,000 Wild Animals Seized," South China Morning Post, 10 June 2003.

${ }^{27}$ Yang Xiaohong and Yi Lin, "Zhongguo linyeju shouci gongbu quanguoxing yesheng dongzhiwu ziyuan diaocha jieguo" (China's Forestry Bureau releases the results of the nation's first-ever nationwide survey of wildlife species), 10 June 2004, <http://news.beelink.com.cn/20040610/1599518.shtml>, accessed 30 July 2005.

${ }^{28}$ King-lun Ngok gives an excellent account of this subordinating role of national legislature to the nation's national economic modernization drive in an article, "Lawmaking and China's Market Transition: Legislative Activism at the Eighth National People's Congress," Problems of Post-Communism 49, no. 2 (2002): 23-32.

${ }^{29}$ Mang Ping, Lüse shenghuo shouji (On green life) (Qingdao: Qingdao Publishing House, 1999), 174.

${ }^{30}$ Li Xiaoxi, "The Urgent Task for Protecting Wildlife Species Is to Revise Relevant Laws," written for the People's Daily (unpublished), April 2003.

${ }^{31}$ Zhang Endi, "Dongwu xuyao zenyang de ai" (What kind of love should we give to animals?), Zhongguo qingnian bao (China youth daily), 12 June 2002.

${ }^{32}$ For a complete list of the protected species under the Chinese Wildlife Protection Law, see "Appendix I: List of State-Protected Wildlife Species," in Zhongguo de baohu dongwu (Protected animals in China), eds Hua Huilun and Yin Jingwen (Shanghai: Shanghai Science and Education Press, 1992), 565-77.

${ }^{33}$ Mang, Lüse shenghuo shouji, 145.

${ }^{34}$ Sun Wufan, "Guangdong ren gai guanguan ziji de zuiba le" (It is time that Cantonese watch what they eat), 30 October 2001, <http://woman.263.net/20010705/00266793.html>, accessed 20 September 2003.

${ }^{35}$ Li Yumin, "Zhengque chuli baohu yesheng dongwu yu qunzhong shengchan huodong de maodun" (Correctly handle the contradictions between wildlife protection and the productive activities of the masses), Chinese Wildlife 15, no. 1 (1994): 3-4.

${ }^{36}$ BBC News, "China to Promote Wildlife Hunt," 9 August 2006, <http://news.bbc.co.uk/go/pr/fr//1/hi/world/asia-pacific/4775335.stm>, accessed 11 August 2006.

${ }^{37}$ Zhang Xue, "Yangzi'e jing ruxi, Nanchang chachu chi 'ye' jiudian" (The Chinese alligators are on the restaurant menu, Nanchang cracks down upon hotels serving "wildlife" food), Jiangxi Daily, 24 April 2003, <http://www.jx.xinhuanet.com/yzsd/2003-04/24/content_426992.htm>, accessed 4 November 2004.

${ }^{38}$ Mang, Lüse shenghuo shouji, 155-9.

${ }^{39} \mathrm{Ma}$ Jianhua and Cheng Chunji, "Fansi 'feidian' yingxiang, tiaozheng falü guifan-you 'feidian' yinfa de sikao" (The impact of SARS and the need to readjust laws and regulations: thoughts evoked by the outbreak of SARS), Chinese Wildlife 24, no. 5 (2003): 52-3.

${ }^{40}$ Personal conversation with Dr Zhang Li in September 2003. See also Li Yumin, "Zhengque chuli baohu yesheng dongwu yu qunzhong shengchan huodong de maodun."

${ }^{41}$ Ibid.

${ }^{42}$ Elizabeth C. Economy, The River Runs Black: The Environmental Challenge of China's Future (Ithaca, NY and London: Cornell University Press, 2004), 100-19.

${ }^{43}$ Wang Xiaogang, "Zhongguo binwei yesheng shengwu qixidi falü baohu duoyuanxing zhi queshi he wanshan: yu Meiguo binwei wuzhong qixidi falü baohu de bijiao" (The shortcomings of China's legal 
protection for the habitat of endangered species and proposals for its improvement: a comparison of

Chinese legal protection with that of the US), Chinese Wildlife 24, no. 5 (2003): 4-5.

${ }^{44} \mathrm{Ma}$ and Cheng, "Fansi 'feidian' yingxiang."

${ }^{45}$ Ibid.

${ }^{46}$ Tang Chendong, Guan Liqin, and Xie Yimin, "Shanghai shi yesheng dongzhiwu ji qi qixidi baohu guanli xianzhuang ji sikao" (Some thoughts on the current state and management of the protection of Shanghai's wildlife animals and plants and their habitat), Chinese Wildlife 24, no. 6 (2003): 50-1.

47 State Forestry Bureau, "Zhongguo ziran baohuqu jianshe de fazhan" (China's progress in the construction of nature reserves), 16 January 2006, <http://www.zhb.gov.cn/eic/650772349473259520/20060116/14619.shtml>, accessed 12 July 2006.

${ }^{48}$ Sen Lin, "Dongwu wangguo li de weiwuerzu fuqi" (The Uighur couple in the kingdom of animals), Chinese Wildlife 20, no. 5 (1999): 42-3.

${ }^{49}$ Zhou Xiangtian, Wu Shibao, and Zhou Weibo, "Cong yiqi teda fanmai chuanshanjia chachu'an yinfa de sikao" (Thoughts from the handling of a major case involving the illegal trade of pangolins), Chinese Wildlife 23, no. 1 (2002): 40-4.

${ }^{50}$ Hao Nan, "'Chi qi zu' de zui shi yesheng dongwu de fenmu" ("Exotic eaters" are the exterminators of China's wildlife species), Chinese Wildlife 20, no. 3 (1999): 2-3.

51 Ibid.

${ }^{52}$ Zhou, Wu, and Zhou, "Cong yiqi teda fanmai chuanshanjia chachu'an yinfa de sikao."

53 See, for example, Bo Zhiyue, "Economic Performance and Political Mobility: Chinese Provincial Leaders," Journal of Contemporary China 5, no. 12 (July 1996): 135-55.

${ }^{54} \mathrm{Li}$ Hongbin and Zhou Li-An, "Political Turnover and Economic Performance: The Incentive Role of Personal Control in China," Journal of Public Economics 89, nos 9-10 (2005): 1743-62.

55 See, for example, John P. Nurns, "Strengthening Central CCP Control of Leadership Selection: The 1990 Nomenklatura," The China Quarterly, no. 138 (1994): 458-501.

${ }^{56}$ Abigail R. Jahiel, "The Contradictory Impact of Reform on Environmental Protection in China," The China Quarterly, no. 149 (1997): 81-104.

57 Jiang Guangquan, "Dui cunmin liesha daxiongmao anjian de fanshi" (A few thoughts about villagers killing giant pandas), Chinese Wildlife 24, no. 6 (2003): 47-8.

${ }^{58}$ Zhou, Wu, and Zhou, "Cong yiqi teda fanmai chuanshanjia chachu'an yinfa de sikao," 43.

${ }^{59}$ Zheng, Zhongguo zhi huimie, 245.

${ }^{60}$ Zhou, Wu, and Zhou, "Cong yiqi teda fanmai chuanshanjia chachu'an yinfa de sikao," 43.

${ }^{61} \mathrm{Hao}$, "Chi qi zu' de zui shi yesheng dongwu de fenmu."

${ }^{62}$ Liu Hao and Guo Yanshu, "Sichuan Tiebu ziran baohuqu meihualu xianzhuang" (The current state of Sichuan spotted deer at Tiebu Nature Reserve), Chinese Wildlife 20, no. 5 (1999): 6-7.

${ }^{63}$ Sen, "Dongwu wangguo li de weiwuerzu fuqi."

${ }^{64}$ He Baisuo, Shi Yaowu, and Yuan Zhaohui, "Shanxi Changqing ziran baohuqu" (Shanxi Changqing Nature Reserve), Chinese Wildlife 20, no. 2 (1999): 4-5; see also Li Chun and Chao Yigong, "Yunnan zhaokai yesheng dongwu ziyuan chixu liyong yu chanyehua fazhan guihua yantaohui" (Yunnan held a development and planning meeting on sustainable use and industrialization of Yunnan's wildlife resources), Chinese Wildlife 20, no. 3 (1999): 45.

65 "Jingjue xuexing de zousi goudang" (Cracking down upon the bloody crime of wildlife smuggling), <http://www.legalinfo.gov.cn/zt/2004-09/15/content_134235.htm>, accessed 20 June 2006.

${ }^{66}$ See, for example, Deng Xiaoping's speech to a visiting foreign dignitary on the need for the Chinese provinces to seek development by utilizing local advantages instead of adopting one uniform model. Leng Rong and Wang Zuoling, Deng Xiaoping nianpu: 1975-1997 (The chronicles of the life of Deng Xiaoping: 1975-1997), Vol. 1 (Beijing: The Central Documentary Press, 2004), 393.

${ }^{67}$ Ma Jianzhang, "Yi jingji jianshe wei zhongxin, kaichuang woguo yesheng dongwu yangzhiye de xin jumian." 
${ }^{68}$ State Forestry Bureau, "Guojia linyeju fabu shangyexing jingying liyong xunyang fanzhi jishu chengshu de 54 zhong lusheng yesheng dongwu mingdan" (The State Forestry Bureau announced the list of 54 land wildlife species whose commercial breeding technology is mature), Chinese Wildlife 24, no. 5 (2003): 51-2.

69 Li Yuming, "Tantan fazhan woguo yesheng dongwu yangzhiye de jige wenti" (On a number of questions regarding China's wildlife farming industry), Chinese Wildlife 19, no. 6 (1998): 26-8.

${ }^{70}$ Personal interview with a Sichuan provincial official in charge of wildlife conservation, 23 November 2003.

${ }^{71}$ Ma Zefang, Zhang Shusen, and Ke Hengshan, "Zhongguo de ronglu yangzhiye" (China's antler deer farming industry), Chinese Wildlife 20, no. 3 (1999): 18.

${ }^{72}$ Liu Jide, "Protect Bear Resource and Benefit Mankind" (paper presented to the Bear Farming Panel at the 19th International Conference of Zoology, Beijing, 25 August 2004).

${ }^{73}$ Chen San, "Bear Breeding and Bile Extraction Is an Effective Way to Conserve and Utilize Bear Resources" (paper presented to the Bear Farming Panel at the 19th International Conference of Zoology, Beijing, 25 August 2004).

${ }^{74} \mathrm{Hu}$ Jiangang, "Zhongguo xibu feifa liesha yesheng dongwu xianzhuang ji fazhi guanli de duice" (The current state of illegal poaching of wildlife animals in Western China: proposed legal and management measures), Chinese Wildlife 22, no. 6 (2001): 28-30.

${ }^{75}$ Zhang Wei, Zhou Xuehong, and Wang Li, "Lun woguo yesheng dongwu yangzhiye de chanyehua jianshe he guifanhua guanli" (On the standardized management and industry construction of China's wildlife farming operation), Chinese Wildlife 25, no. 3 (2004): 27.

76 "Woguo yesheng dongwu ziyuan xianzhuang," 3.

77 Zhou Xiping, "Shanxi Implements Wildlife Business and Processing License Mechanism," Chinese Wildlife 18, no. 5 (1997): 15.

${ }^{78}$ Wang Zipeng, "2000 nian Zhongguo yesheng dongzhiwu jinchukou maoyi zhuangkuang" (China's import and export of animal and plant products in 2000), Chinese Wildlife 24, no. 4 (2003): 49-54.

${ }^{79}$ Zheng, Zhongguo zhi huimie, 431.

${ }^{80}$ Wang, "2000 nian Zhongguo yesheng dongzhiwu jinchukou maoyi zhuangkuang."

${ }^{81}$ Zheng, Zhongguo zhi huimie, 431.

${ }^{82}$ Clifton, "SARS Shuts Live Markets."

83 Reuters, "Russia Seizes China-bound Truck with 800 Bear Paws," 23 March 2004 <http://www.enn.com/news/2004-03-23/s_14242.asp>, accessed 10 July 2004.

84 Pravda, "\$15 Billion a Year on Illegal Trade," 17 November 2003, <http://newsfromrussia.com/main/2003/11/17/51297.html>, accessed 20 July 2004.

${ }^{85} \mathrm{Hu}$ Jiangang, "Zhongguo xibu feifa liesha yesheng dongwu xianzhuang ji fazhi guanli de duice."

${ }^{86}$ Ibid.

${ }^{87}$ Zhou, Wu, and Zhou, "Cong yiqi teda fanmai chuanshanjia chachu'an yinfa de sikao."

${ }^{88}$ Economy, The River Runs Black, 20-1.

89 "Imported Chinese Traditional Medicine Drugs Accounted for 1/5 of the Domestic Market," Hong Kong Commercial News, 29 July 2004, <http://news.creaders.net/headline/newsPool/29A210683.html>, accessed 12 June 2005.

${ }^{90}$ Conversation with Joyce D'Silva, director of Compassion in World Farming, 24 August 2004.

${ }^{91}$ Henry Sim Kwong Lee, "Withdraw the Use of Animals and TCM Will Be Fit to Challenge the European Union (EU) Directive and to Assure Itself a Healthy Future beyond the Shores of China," speech delivered at the 19th International Conference of Zoology, Beijing, 25 August 2004.

92 Liang Chongjie, "Political Consultative Conference Legislative Proposal on the Need to Speed up the Efforts to Revise the Current Wildlife Protection Law," 28 April 2003, <http://www.fon.org.cn/index.php?id=3287\&s=3412>, accessed 20 September 2003. 
${ }^{93}$ Liu Wenyan, "Lun yesheng dongwu baohu lifa de shengtai jiazhi linian jichu" (On using ecological value as the basis of wildlife protection legislation), ChineseWildlife 24, no. 6 (2003): 15-16.

${ }^{94}$ Liang, "Political Consultative Conference Legislative Proposal."

95 Jiang Zhigang, "Yesheng dongwu' gainian zhuyi" (On the concept of "wildlife animals"), Chinese Wildlife 24, no. 4 (2003): 2.

${ }^{96}$ Liang, "Political Consultative Conference Legislative Proposal."

${ }^{97}$ Mang Ping, "Wei suoyou dongwu bu shou nüedai-huyu lifa: fan nüedai dongwu fa'an" (To protect all animals from cruelty: a call for immediate anticruelty legislation), Zhongguo qingnian bao (China youth daily), 13 March 2002, <http://www.fon.org.cn/content.php?aid=7521>, accessed 12 July 2004.

98 "China Mulls First Animal Rights Law," 17 May 2004, <http://www.taipeitimes.com/News/feat/archives/2004/05/17/2003155907>, accessed 20 May 2004.

${ }^{99} \mathrm{Hu}$ Jun, "Gai bu gai wei dongwu fuli lifa?" (Should a law not be enacted to protect animal welfare?), 18 May 2004, <http://www.ycwb.com/gb/content/2004-05/18/content 693002.htm>, accessed 2 November 2004.

${ }^{100}$ Ma and Cheng, "Fansi 'feidian' yingxiang," 53.

101 See Elizabeth C. Economy's account of the pressures China's Friends of Nature faced when the Chinese government demanded dismissal of one of its cofounders, The River Runs Black, 145-9.

102 Personal conversations and electronic communication with Chinese activists in Beijing, 10 February 2004 and 20 January 2005.

103 Tang Xiyang and Marcia Marks, Huanqiu lüse xing (A green world tour) (Beijing: New World Press, 1999), cited in Economy, The River Runs Black, 140.

\section{References}

BBC News. "China to Promote Wildlife Hunt." 9 August 2006. <http://news.bbc.co.uk/go/pr/fr//1/hi/world/asia-pacific/4775335.stm>, accessed 11 August 2006.

Bo, Zhiyue. "Economic Performance and Political Mobility: Chinese Provincial Leaders." Journal of Contemporary China 5, no. 12 (1996): 135-55.

Cai, Shouqiu. Huanjing ziyuan faxue jiaocheng (Textbook on environmental and resource laws). Wuhan: Wuhan University Press, 2002.

Chen, San. "Bear Breeding and Bile Extraction Is an Effective Way to Conserve and Utilize Bear Resources." Paper presented to the Bear Farming Panel at the 19th International Conference of Zoology, Beijing, 25 August 2004.

China Biodiversity Office. "Executive Summary." The First State Report on China's Execution of the "Convention on Biological Diversity." 112004. <http://www.biodiv.gov.cn/swdyx/145241087982698496/20040301/1046429.shtml>, accessed 2 July 2006.

"China Mulls First Animal Rights Law." 17 May 2004. <http://www.taipeitimes.com/News/feat/archives/2004/05/17/2003155907>, accessed 20 May 2004.

Clifton, Merritt. "SARS Shuts Live Markets-May Change Chinese Menus." Animal People, 30 June 2003. <http://www.animalpeoplenews.org/03/6/SARSshutsmarkets6.03.html>, accessed 12 July 2006.

Economy, Elizabeth C. The River Runs Black: The Environmental Challenge of China's Future. Ithaca, NY and London: Cornell University Press, 2004.

Forestry Bureau. "Guojia baohu de youyi de huozhe you zhongyao jingji, kexue yanjiu jiazhi de lusheng yesheng dongwu minglu" (List of state-protected terrestrial species that are beneficial and of important economic and scientific research value). State Forestry Bureau Order no. 7. 2000. <http://vip.chinalawinfo.com/Newlaw2002/SLC/SLC.asp?Db=chl\&Gid=36047>, accessed 18 June 2006. 
Forestry Ministry. "Linyebu guanyu hezhun bufen binwei yesheng dongwu wei guojia zhongdian baohu yesheng dongwu de tongzhi" (Notice on approving the inclusion of certain endangered species in the state-protected lists). Forestry Ministry Notice no. 48. 14 April 1993. <http://vip.chinalawinfo.com/Newlaw2002/SLC/SLC.asp?Db=chl\&Gid=9694>, accessed 29 June 2006.

Forestry Ministry, and Agriculture Ministry of the People's Republic of China. "Guojia zhongdian baohu yesheng dongwu minglu" (List of wildlife species under state protection). 14 January 1989. <http://vip.chinalawinfo.com/Newlaw2002/SLC/SLC. asp?Db=chl\&Gid=7138>, accessed 2 July 2005.

Forestry Ministry, and Public Security Ministry. "Guojia linyebu gong'anbu guanyu senlin he lusheng yesheng dongwu xingshi anjian de guanxia ji li'an biaozhun de guiding" (Rules on the standards for managing and starting a criminal investigation of cases involving terrestrial wildlife animals). 1994. <http://law.chinalawinfo.com/newlaw2002/SLC/SLC.asp?Db=chl\&Gid=35431>, accessed 18 July 2006.

Forestry Ministry, Finance Ministry, and State Price Administration. "Lusheng yesheng dongwu ziyuan baohu guanlifei shoufei banfa" (Measures for the collection of administration fees for protecting terrestrial wildlife resources). Forestry Protection Document no. 72.1992. <http://vip.chinalawinfo.com/Newlaw2002/SLC/SLC.asp?Db=chl\&Gid=15636>, accessed 18 July 2006.

Geng, Biao. Geng Biao huiyi lu: 1949-1992 (Geng Biao remembers: 1949-1992). Nanjing: Jiangsu People's Press, 1998.

Hao, Nan. "Chi qi zu' de zui shi yesheng dongwu de fenmu" ("Exotic eaters" are the exterminators of China's wildlife species). Chinese Wildlife 20, no. 3 (1999): 2-3.

$\mathrm{He}$, Baisuo, Shi Yaowu, and Yuan Zhaohui. "Shanxi Changqing ziran baohuqu" (Shanxi Changqing Nature Reserve). Chinese Wildlife 20, no. 2 (1999): 4-5.

Hsieh-Yi, Yi-Chiao, Yu Fu, Mark Rissi, and Barbara Maas. "Fun Fur? A Report on the Chinese Fur Industry." Report jointly sponsored by the Swiss Animal Protection SAP, Care for the Wild International, and EAST International. 2005.

$\mathrm{Hu}$, Jiangang. "Zhongguo xibu feifa liesha yesheng dongwu xianzhuang ji fazhi guanli de duice" (The current state of illegal poaching of wildlife animals in Western China: proposed legal and management measures). Chinese Wildlife 22, no. 6 (2001): 18-28.

Hu, Jun. "Gai bu gai wei dongwu fuli lifa?" (Should a law not be enacted to protect animal welfare?). 18 May 2004. <http://www.ycwb.com/gb/content/2004-05/18/content_693002.htm>, accessed 2 November 2004.

Hua, Huilun, and Yin Jingwen, eds. Zhongguo de baohu dongwu (Protected animals in China). Shanghai: Shanghai Science and Education Press, 1992.

"Imported Chinese Traditional Medicine Drugs Accounted for 15 of the Domestic Market." Hong Kong Commercial News, 29 July 2004. <http://news.creaders. net/headline/newsPool/29A210683.html>, accessed 12 June 2005.

Jahiel, Abigail R. "The Contradictory Impact of Reform on Environmental Protection in China." The China Quarterly, no. 149 (1997): 81-104.

Jiang, Guangquan. "Dui cunmin liesha daxiongmao anjian de fanshi" (A few thoughts about villagers killing giant pandas). Chinese Wildlife 24, no. 6 (2003): 47-8.

Jiang, Zhigang. "'Yesheng dongwu' gainian zhuyi" (On the concept of "wildlife animals"). Chinese Wildlife 24, no. 4 (2003): 2.

Jing, Ruilin. Huanjing faxue (The study of environmental law). Beijing: Beijing University Press, 2002.

"Jingjue xuexing de zousi goudang" (Cracking down upon the bloody crime of wildlife

smuggling). <http://www.legalinfo.gov.cn/zt/2004-09/15/content_134235.htm>,

accessed 20 June 2006. 
Lee, Henry Sim Kwong. "Withdraw the Use of Animals and TCM Will Be Fit to Challenge the European Union (EU) Directive and to Assure Itself a Healthy Future beyond the Shores of China." Speech delivered at the 19th International Conference of Zoology, Beijing, 25 August 2004.

Leng, Rong, and Wang Zuoling. Deng Xiaoping nianpu: 1975-1997 (The chronicles of the life of Deng Xiaoping: 1975-1997). Vol. 1. Beijing: The Central Documentary Press, 2004.

$\mathrm{Li}$, Chun, and Chao Yigong. "Yunnan zhaokai yesheng dongwu ziyuan chixu liyong yu chanyehua fazhan guihua yantaohui" (Yunnan held a development and planning meeting on sustainable use and industrialization of Yunnan's wildlife resources). Chinese Wildlife 20, no. 3 (1999): 45.

$\mathrm{Li}$, Hongbin, and Zhou Li-An. "Political Turnover and Economic Performance: The Incentive Role of Personal Control in China." Journal of Public Economics 89, nos 9-10 (2005): 1743-62.

$\mathrm{Li}$, Xiaoxi. "The Urgent Task for Protecting Wildlife Species Is to Revise Relevant Laws." Written for the People's Daily (unpublished), April 2003.

$\mathrm{Li}$, Yuming. "Zhengque chuli baohu yesheng dongwu yu qunzhong shengchan huodong de maodun" (Correctly handle the contradictions between wildlife protection and the productive activities of the masses). Chinese Wildlife 15, no. 1 (1994): 3-4.

$\mathrm{Li}$, Yuming. "Tantan fazhan woguo yesheng dongwu yangzhiye de jige wenti" (On a number of questions regarding China's wildlife farming industry). Chinese Wildlife 19, no. 6 (1998): 26-8.

Liang, Chongjie. "Political Consultative Conference Legislative Proposal on the Need to Speed up the Efforts to Revise the Current Wildlife Protection Law." 28 April 2003. <http://www.fon.org.cn/index.php?id=3287\&s=3412>, accessed 20 September 2003.

Liu, Hao, and Guo Yanshu. "Sichuan Tiebu ziran baohuqu meihualu xianzhuang" (The current state of Sichuan spotted deer at Tiebu Nature Reserve). Chinese Wildlife 20, no. 5 (1999): 6-7.

Liu, Jide. "Protect Bear Resource and Benefit Mankind." Paper presented to the Bear Farming Panel at the 19th International Conference of Zoology, Beijing, 25 August 2004.

Liu, Ping, and Su Shugen. "Qing zuixia liuqing" (Please watch what you eat). Chinese Wildlife 22, no. 4 (2001): 28-9.

Liu, Wenyan. "Lun yesheng dongwu baohu lifa de shengtai jiazhi linian jichu" (On using ecological value as the basis of wildlife protection legislation). ChineseWildlife 24, no. 6 (2003): 15-16.

$\mathrm{Ma}$, Jianhua, and Cheng Chunji. 'Fansi 'feidian' yingxiang, tiaozheng falü guifan-you 'feidian' yinfa de sikao" (The impact of SARS and the need to readjust laws and regulations: thoughts evoked by the outbreak of SARS). Chinese Wildlife 24, no. 5 (2003): 52-3.

$\mathrm{Ma}$, Jianzhang. "Yi jingji jianshe wei zhongxin, kaichuang woguo yesheng dongwu yangzhiye de xin jumian" (Create a new situation in China's wildlife farming under the banner of economic construction as the national priority). Chinese Wildlife, no. 4 (1992): 12-14.

$\mathrm{Ma}$, Zefang, Zhang Shusen, and Ke Hengshan. "Zhongguo de ronglu yangzhiye" (China's antler deer farming industry). Chinese Wildlife 20, no. 3 (1999): 18.

Mang, Ping. Lüse shenghuo shouji (On green life). Qingdao: Qingdao Publishing House, 1999.

Mang, Ping. "Wei suoyou dongwu bu shou nüedai-huyu lifa: fan nüedai dongwu fa'an" (To protect all animals from cruelty: a call for immediate anticruelty legislation). Zhongguo qingnian bao (China youth daily), 13 March 2002. <http://www.fon.org.cn/content.php?aid=7521>, accessed 12 July 2004.

Ngok, King-lun. "Law-Making and China's Market Transition: Legislative Activism at the Eighth National People's Congress." Problems of Post-Communism 49, no. 2 (2002): 23-32.

Nurns, John P. "Strengthening Central CCP Control of Leadership Selection: The 1990 Nomenklatura." The China Quarterly, no. 138 (1994): 458-501.

Pravda. "\$15 Billion a Year on Illegal Trade." 17 November 2003. <http://newsfromrussia.com/main/2003/11/17/51297.html>, accessed 20 July 2004.

Reuters. "Russia Seizes China-bound Truck with 800 Bear Paws." 23 March 2004. <http://www.enn.com/news/2004-03-23/s_14242.asp>, accessed 10 July 2004. 
Ross, Emma. "Blood Tests on Market Workers Strengthen SARS Link between Animals and Humans." Associated Press Report, 27 May 2003.

Sen, Lin. "Dongwu wangguo li de weiwuerzu fuqi" (The Uighur couple in the kingdom of animals). Chinese Wildlife 20, no. 5 (1999): 42-3.

Shapiro, Judith. Mao's War against Nature: Politics and the Environment in Revolutionary China. Cambridge: Cambridge University Press, 2001.

State Council. "Guowuyuan guanyu jiji baohu he heli liyong yesheng dongwu ziyuan de zhishi" (State Council instructions on actively protecting and reasonably using animal resources). 14 September 1962. <http://www.people.com.cn/GB/33831/33836/34143/34234/2551386.html>, accessed 20 April 2006.

State Council. "Guowuyuan guanyu yange baohu zhengui xiyou yesheng dongwu de tongling" (State Council Order on strictly protecting rare and endangered wildlife species). State Council Order no. 62. 1983. <http://vip.chinalawinfo.com/Newlaw2002/SLC/SLC.asp?Db=chl\&Gid=1605>, accessed 20 April 2006.

State Forestry Bureau. "Guojia linyeju fabu shangyexing jingying liyong xunyang fanzhi jishu chengshu de 54 zhong lusheng yesheng dongwu mingdan" (The State Forestry Bureau announced the list of 54 land wildlife species whose commercial breeding technology is mature). Chinese Wildlife 24, no. 5 (2003): 51-2.

State Forestry Bureau. "Zhongguo ziran baohuqu jianshe de fazhan" (China's progress in the construction of nature $\quad$ reserves). $16 \quad$ January 2006. <http://www.zhb.gov.cn/eic/650772349473259520/20060116/14619.shtml>, accessed 12 July 2006.

Sun, Wufan. "Guangdong ren gai guanguan ziji de zuiba le" (It is time that Cantonese watch what they eat). 30 October 2001. <http://woman.263.net/20010705/00266793.html>, accessed 20 September 2003.

Tang, Chendong, Guan Liqin, and Xie Yimin. "Shanghai shi yesheng dongzhiwu ji qi qixidi baohu guanli xianzhuang ji sikao" (Some thoughts on the current state and management of the protection of Shanghai's wildlife animals and plants and their habitat). Chinese Wildlife 24, no. 6 (2003): 50-1.

Tang, Xiyang, and Marcia Marks. Huanqiu lüse xing (A green world tour). Beijing: New World Press, 1999.

Wang, Zipeng, "2000 nian Zhongguo yesheng dongzhiwu jinchukou maoyi zhuangkuang" (China's import and export of animal and plant products in 2000). Chinese Wildlife 24, no. 4 (2003): 49-54.

Wang, Xiaogang. "Zhongguo binwei yesheng shengwu qixidi falü baohu duoyuanxing zhi queshi he wanshan: yu Meiguo binwei wuzhong qixidi falü baohu de bijiao" (The shortcomings of China's legal protection for the habitat of endangered species and proposals for its improvement: a comparison of Chinese legal protection with that of the US). Chinese Wildlife 24, no. 5 (2003): 4-5.

"Woguo yesheng dongwu ziyuan de xianzhuang" (The current state of China's wildlife resources). Chinese Wildlife, no. 3 (1989): 3-4 (no author).

Xinhua News Agency. "Shanghai dongwuyuan xiugai shuomingpai 'rou ke shi' 'haishou' deng bei tichu" (Shanghai Zoo revises the information boards to eliminate descriptions such as "flesh can be eaten" and "harmful pests"). 4 March 2002. <http://www.china.org.cn/chinese/TR-c/113746.htm>, accessed 28 July 2006.

$\mathrm{Xu}$, Gang. "Zhongguo yesheng dongwu xianzhuang" (The current state of China's wildlife animals). Friends of Nature report, 5 March 1997. <http://cn.greenstone.org/epi/read.php?id=166>, accessed 27 July 2005.

Yang Xiaohong and Yi Lin. "Zhongguo linyeju shouci gongbu quanguoxing yesheng dongzhiwu ziyuan diaocha jieguo" (China's Forestry Bureau releases the results of the nation's first-ever nationwide survey of wildlife species). 10 June 2004. <http://news.beelink.com.cn/20040610/1599518.shtml>, accessed 30 July 2005.

Yu, Hu. "10,000 Wild Animals Seized." South China Morning Post, 10 June 2003. 
Zhang, Endi. "Dongwu xuyao zenyang de ai" (What kind of love should we give to animals?). Zhongguo qingnian bao (China youth daily), 12 June 2002.

Zhang, Wei, Zhou Xuehong, and Wang Li. "Lun woguo yesheng dongwu yangzhiye de chanyehua jianshe he guifanhua guanli" (On the standardized management and industry construction of China's wildlife farming operation). Chinese Wildlife 25, no. 3 (2004): 27-8.

Zhang, Xue, "Yangzi'e jing ruxi, Nanchang chachu chi 'ye' jiudian" (The Chinese alligators are on the restaurant menu, Nanchang cracks down upon hotels serving "wildlife" food). Jiangxi Daily, 24 April 2003. <http://www.jx.xinhuanet.com/yzsd/2003-04/24/content_426992.htm>, accessed 4 November 2004

Zheng, Yi. Zhongguo zhi huimie: Zhongguo shengtai bengkui jinji baogao (China's ecological winter). Hong Kong: The Mirror Books, 2001.

Zhou, Xiangtian, Wu Shibao, and Zhou Weibo. "Cong yiqi teda fanmai chuanshanjia chachu'an yinfa de sikao" (Thoughts from the handling of a major case involving the illegal trade of pangolins). Chinese Wildlife 23, no. 1 (2002): 40-4.

Zhou, Xiping. "Shanxi sheng shixing yesheng dongwu jingying jiagong xukezheng zhidu" (Shanxi implements wildlife business and processing license mechanism). Chinese Wildlife 18, no. 5 (1997): 15-16. 